\title{
The Role of Government Capital Expenditures in Economic Growth in Jordan
}

\author{
Basema Al-Sharif ${ }^{1, ~ *, ~ A d e l ~ B i n o ~}{ }^{2}$ \\ ${ }^{1}$ Department of Finance, School of Business, University of Jordan, Amman, Jordan \\ ${ }^{2}$ Department of Economy, School of Business, University of Jordan, Amman, Jordan \\ Email address: \\ alsharif.basema@gmail.com (B. Al-Sharif), a.bino@ju.edu.jo (A. Bino) \\ ${ }^{*}$ Corresponding author
}

To cite this article:

Basema Al-Sharif, Adel Bino. The Role of Government Capital Expenditures in Economic Growth in Jordan. International Journal of Business and Economics Research. Vol. 8, No. 2, 2019, pp. 69-77. doi: 10.11648/j.ijber.20190802.15

Received: February 22, 2019; Accepted: April 12, 2019; Published: May 23, 2019

\begin{abstract}
This research aims at examining the role of government capital expenditures in economic growth in Jordan during the time period (1977-2016). The study collects the required data from the Central Bank of Jordan, the Department of Statistics, and the Ministry of Finance database. The analyzes is based on estimating the output as a function of input and control variables and analyzing the Gross Domestic Product (GDP) as a function of the total capital expenditures. The study found that first, the change in capital expenditures as a percentage of GDP has long-term equilibrium and has a short-term effect, but this result is unreliable due to model instability. Second, there is a short-term impact of net fixed capital formation and net tax on economic growth but there is no long-term equilibrium, and finally there is a short-term and long-term effect of government debt on economic growth. These findings can provide significant insights into many aspects of implementing policy in Jordan.
\end{abstract}

Keywords: Economic Growth, Capital Expenditures, Gross Fixed Capital Formation, Net Tax, Government Debt

\section{Introduction}

Government legislation on public expenditures plays an essential role in fostering economic growth by balancing the country's revenues and expenditures. In Jordan [3] claimed when the economy experiences recession, increased government spending will elicit a rise in the aggregate demand thereby assisting the economy to gradually recover. Intuitively, public expenditures improve economic growth by increasing productive capacity, as well as, gross product of the local economy, especially in critical economic sectors [3]. Nonetheless, increased public expenditures will also lead to inflation and reduce government budget, thereby inflicting detrimental influence on the economic performance of a country [13]. Reportedly, capital spending is one of the critical elements of public expenditures for the detailed and sustainable economic growth of a country. Nonetheless, the issue of the management, expenditures, as well as, distribution of capital expenditures in an equal manner to realize economic growth in each fiscal year is a daunting task.

Data from the Department of Statistics (DOS) in Jordan show that public expenditures have been increasing since 1970. However, the country's economy has been sluggish for many years. Therefore, this decline in the economic growth despite gradual increase in public expenditures has elicited debate on whether increased public expenditures especially capital spending can actually contribute to economic growth. Therefore, the proposed study seeks to investigate the impact of government capital expenditures on economic growth in Jordan. Based on the findings of the study, different solutions and recommendations will be proposed to enhance budget spending performance, minimize losses, wasteful use of public expenditures, and thereby boosting economic growth of the country.

\subsection{Background}

For many years, the impact of government capital expenditures on economic growth has elicited heated debate among policy makers and researchers. The 
common agreement among researchers is that capital expenditures are an essential instrument that the government uses to influence the economic growth of its country [28]. Despite such consensus, the impact of total government capital spending on economic growth remains contentious. Udoka and Anyingang [27] stated that the connection between government capital spending and economic growth is essential particularly for developing nations, most of which have witnessed a growth in capital expenditures over time. On the contrary, [25] stated that there is no universal agreement regarding the influence of government capital spending on economic growth. In Italy [17] contended that the impact is negative while in Iran [20] claimed that there is substantive conclusion regarding the impact of government capital spending on economic growth.

Theoretically, government spending especially capital expenditures is a source of economic stability. This reasoning concurs with Keynesian macroeconomic framework, the standard effective demand theory states that an increase in government spending results in increasing aggregate demand that stimulates economic growth. Nonetheless, Post-Keynesian economists contend that increasing government spending particularly, capital expenditures is a central cause of business cycle instability and leads to recession in the long run. Contrarily, the law of increasing spending postulated by Wagner argues that government spending is an endogenous factor and not a cause of economic growth and development.

Empirically, the evidences deduced signify a more mixed picture. Some economists support government spending as they assert that it drives economic growth [14]. They contend that government spending on infrastructures stimulates economic growth. Besides, government spending on education and health improves labor productivity and enhances growth of national output [16]. More importantly, expenditures on infrastructure including power, communications, and roads lowers production costs, improves private sector investment, and profitability of companies thus stimulating economic growth [23]. However, some scholars oppose the claim that government spending fosters economic growth. Instead, they state that increased government expenditures may restrain overall economic performance [27]. Their argument is anchored on the fact that in its attempts to fund the growing expenditure; the government may increase borrowing and taxation [27]. However, from economic perspective, increased income taxation discourages people from working for many hours or possibly looking for lucrative jobs, thus lowers aggregate demand and income [28]. Similarly, increased profit tax increases costs of production, lowers investment expenditure, and firms' profitability [4]. Moreover, when the government increases borrowing to fund its capital expenditure, there is possibility of it crowding out private sector thereby lowering private investment [23].

Because of these divergent views, there is a growing need to examine whether government capital expenditures lead to economic growth or whether government capital spending is the epitome of economic growth in Jordan.

\subsection{Problem Statement}

The economic performance of Jordan has remained relatively low amidst its challenging environment. Recently, the government has increased its capital expenditures to improve the country's developmental needs. It has also adopted explicit target for its capital spending to monitor the fiscal situation and attain sustainable growth. Despite these efforts, little economic growth has been realized and thus questions continue to emerge on the impact of government capital expenditures on the country's economic growth. Besides, with varied views concerning capital spending, it is unclear whether the Jordanian government should continue to increase its capital expenditures or should set a capital expenditures limit. Furthermore, no studies have been conducted in the past to establish how government capital expenditures influence economic growth in Jordan. Therefore, the question on whether government capital spending results in economic growth or instability in Jordan is yet to be established. For this reason, the proposed study seeks to uncover this dilemma and provide a way forward for the Jordanian government regarding its capital expenditure.

\subsection{Study Objectives}

The objective of this study on government capital expenditures and economic growth in Jordan is to investigate the association between capital expenditures and overall economic growth.

\subsection{Research Questions}

The proposed study will be guided by the following question:

1. What is the relationship between capital expenditures and economic growth?

\section{Literature Review}

Past studies have comprehensively investigated government capital expenditures and economic growth, particularly in developing countries. The above concepts generate much research interests due to their conflicting and long-lasting state in economic theory. For these reasons, this chapter reviews theories and empirical studies conducted on this topic. Principally, there is a causal relationship between government capital expenditures and economic growth since the former dictates the economic performance of a country.

\subsection{Government Spending and Growth}

There is some research evidence to suggest that the use of government spending as a fiscal policy tool has an adverse effect on the economy [19]. It is a widely held view by many researchers that positive government spending has a constructive effect on economic output and growth. For instance, the study by Blanchard and Perotti [9] notes that 
positive government spending shocks have a constructive effect on output, as well as private consumption. The authors define positive shocks in government spending as an increase in the total purchases of goods and services, including government consumption and investment. A later study by Giordano et al., [20] examined the impact of fiscal policy in Italy using evidence obtained from the VAR model. The study uses 6 VAR variables to represent total direct government spending, including employment, private GDP deflator, private GDP, interest rate, net revenue, and direct expenditures. The results obtained by Giordano et al. [20] are consistent with those of Blanchard and Perotti [9], indicating that direct government expenditures can have a positive impact of economic output. Fatásand Mihov [17] also provide a relevant account of the impact of government spending on the progress of the economy. Specifically, the authors observe that an increase in government spending causes an expansionary effect with the output increasing in a ratio that is more than $1: 1$. [17] further note that the expansionary effect is always followed by an increase in consumption. However, the standard Real Business Cycle model used in the study fails to account for the empirical response on consumption and employment [17], likely to be experienced during an increase in government spending. From these studies, it is possible to claim that high government spending produces obstinately advanced nominal and real interest rates, possibly due to insistently higher net borrowing.

Recent research reports also indicate that an upsurge in government spending can have a sturdy negative impact on investment spending and economic growth. Such an argument is evident in the study by Blanchard and Perotti [9], who find a strong and negative impact of increased government spending on private investment spending. A similar observation is apparent in a recent study by De Castro [15], examining the macroeconomic impact of fiscal policy in Spain. The research empirically illustrates that a shock in government spending can result in a negative response on output and private investment. This effect can be justified based on the existing perception that government spending affects public wages and increases the pressure on investment profitability [15]. Stated otherwise, de Castro sees government expenditures as one of the key reasons for the arising public deficit.

There is also a common presumption among scholars that fiscal shocks have a significant impact on government debt feedback. Afonso and Sousa [2] examine this perspective using a Bayesian Structural Vector Autoregression approach based on empirical evidence collected from the US, UK, Germany, and Italy. While the study makes varying observations across the four countries, the general indication is that shocks in government spending have a minimal impact on Gross Domestic Product (GDP). Besides, these shocks can also have a varying impact on housing prices and can result in a change in stock prices. Based on these observations, Afonso and Sousa [2] recommend the need for governments to explicitly consider the debt dynamics when making decisions to use spending as a fiscal policy tool. Favero and Giavazzi [18] make similar observations by claiming that a constructive shock to government spending can have two possible directions. The first option would be for the government to honor its budget constraint by altering taxes and spending to maintain a stable ratio of debt-to-GDP. Alternatively, the second option would be to delay such adjustments and allow the debt ratio to increase. The implication of these findings is that considering the debt dynamics can somewhat minimizes the government spending shock on GDP, private consumption, as well as private investment.

Recent literature shows that the structure, size, as well as, growth of government capital expenditures has increased significantly and become progressively complex. Liu, Lopez and Zhu [22] noted that not only has the contemporary political developments stimulated expenditures growth, the problem of acquiring additional and finding alternative revenue sources to fulfill the ever growing demands of governance has made it more critical to examine government activities, particularly its capital expenditures. Scholars across the globe have tried to investigate the causal relationship that exists between government capital expenditures on economic growth in various nations and periods. In particular, a study by Al Bataineh [3] examined the effect of public expenditures on the economic growth of Jordan. The study adopted Vector Autoregressive approach using time series data for the years 1963- 2008 to assess the influence of government expenditures on the economic growth. Intuitively, showed a long run relationship between GDP growth rates and chose elements of public expenditures. From the study, it was deduced that the composition of government expenditures and public expenditures reforms influence economic growth.

On the same note, Al-Fawwaz [4] conducted a research to describe the connection between public expenditures and economic growth in Jordan using Vector Error Correction Model (VECM). The researcher adopted time series data for the period 1963- 2012. Using Vector Error Correction Model, the researcher estimated the long run and short run relationship between public expenditures and economic growth. The finding of the study revealed that elements of public expenditures and economic growth shift towards long run equilibrium with a speed of $3.6 \%$ following a short turn shifts in the equilibrium. In addition, there was no positive relationship detected between public expenditures and economic growth. However, the study findings showed a unidirectional relationship between health and military expenditures. Therefore, it was a recommended that there should be an increase in the health allocation to realize positive economic growth in the future.

In another study, Abu-Eideh [1] examined how government expenditures influence economic growth of Asian countries. In addition, the study sought to establish whether there is a long run relationship between economic growth and public expenditures. Some of the nations included in the research encompassed South Korea, Sri 
Lanka, Bhutan and others with approximately 45 observations in every country from the period 1970-2013. In the study, random effect panel OLS model approach was adopted. The results revealed that government expenditures positively influence economic growth in the region. Further, it was reported that both economic growth and government expenditures showed a long run connection within the Asian nations. From these findings, it was deduced that there exists a unidirectional relationship between government expenditures and economic growth in Asian countries and that the former plays an essential role in the economic performance of each country.

Colombier [13] carried out a study to determine the relationship that exists between public expenditures and GPD for the US using data for the period 1947-2002. Intuitively, the causality relationship indicated that total government expenditures have positive effects on the GDP growth. The research of the study further indicated that growth in GDP hardly expands government expenditures. From the estimation findings, it was revealed that public expenditures improve the economic growth of the US. Based on these findings, the author summarized that judging on the relationship test, Keynesian hypothesis piles more pressure than the Wagner's law in the case of US.

Al-Shatti [6] also reported a long-term connection between government expenditures and economic growth for the years 1970 in Jordan. In addition, the results of the study revealed that recurrent expenditures pile more pressure as compared to capital expenditures on growth. On a similar note, Al-Fawwaz [4] examined the effect of public expenditures on economic performance of Jordan for the period 1981-2011. From the study, it was concluded that government capital expending on infrastructures and agriculture if correctly managed improves the country's production capacity, as well as, employment that consequently enhances the economic growth of Jordan. The study recommended that the government should increase its capital on electricity and rural roads because this will improve productive sector and improve the living standards of its people. On the same note, while examining the influence of government expenditures on the economic growth in Jordan, Dandan [14] established that the total capital spending on education has significantly improved GDP. The study recommended that the government need channel its expenditures to productive sectors including infrastructure since doing this will minimize expenses associated with doing business and improve the living standards of the citizens. Similarly, Dritsakis and Adamopoulos [16] resolved that the government needs to ensure that capital expenditures are correctly managed in order to improve the production capacity of its country. Further, the author suggested that there is need for the Jordanian government to allocate more funds on education, telecommunication, health and security as they are crucial and significant influence on the economic performance of a country. From these studies, it can be concluded that there exists a causal relationship between government capital expenditures and economic growth.

To summarize, from the reviewed literature, fiscal reforms affect economic development through two key channels taxation and government spending. In most cases, governments have control over both taxes and government spending. Most scholars agree that lowering of taxes and the raising of government spending can increase the quantity of money available to the population, a strategy often referred to as expansionary fiscal policy. However, the government can also use the fiscal policy to reduce the amount of money available to the populace, a strategy referred to as a contractionary fiscal policy. A contractionary fiscal policy may involve increasing the amount of taxes, as well as reducing government spending. While many studies have examined the relationship between fiscal policy and economic development, few studies have focused on using variables from specific countries. Most studies use data from OECD countries, while others focus on well-performing countries, such as the US, UK, Germany, and Italy. Hence, there is a research gap to examine how fiscal policies affect economic development in Jordan, a country that was heavily affected by various external factors, such as significant decline in external grants and a decline in tax receipts.

\subsection{Capital Expenditures and Infrastructural Growth}

Studies have revealed that capital expenditures on public infrastructure increases productivity of private and public sectors thus improving economic growth. Kaur, Kirandeep, and OnkarNath Mishra [21] asserted that as a contributor to economic growth, capital expenditures on energy infrastructure lowers production costs, diversifies production into higher return activities and improves people's living standards and well beings. The study further reported that increasing capital expenditures for public infrastructural growth is a priority for governments. In another study, Dritsakis and Adamopoulos [16] asserted that government spending on infrastructure stimulates economic growth. The study revealed that government spending particularly on health and education enhances labor productivity and improves growth of national output. More importantly, expenditures on infrastructure including power, communications, and roads improves investment of private sectors, reduces costs of production and increases profitability of companies thereby improving economic growth.

In another study, Mehrara, Abrishami, Boroujli, and Amin [23] examined the connection between government investment in infrastructure and economic growth in Iran. The study employed a descriptive study design where focus was on secondary data on government development expenditures obtained from the country's economic survey report. Principally, the data encompassed government investments in infrastructure an economic growth data from the government that covered a period of ten years (20052014). The findings of the study revealed that government investment in infrastructural development had a significant and positive influence on the economic growth in Iran for 
the period of this study. Principally, the study recommended that sufficient funds should be channeled towards preparation, implementation and maintenance of infrastructure projects.

Udoka and Anyingang [27] also sought to determine the influence of financing infrastructure projects partnership between public and private sectors on physical infrastructure growth in Nigeria. The study employed a descriptive survey and a cluster sampling of 60 infrastructure projects from the list retrieved from PublicPrivate Partnership unit and medium-term expenditures framework reports of 2013. The study employed a multiple regression model to analyze the data. The findings of the study revealed a direct causal relationship between government investment on infrastructure and economic growth.

\subsection{Research Contribution}

The contribution of the study presents from two prospective points:

1. Many literatures in the proposed study have presented mixed findings on the relationship that exist between government capital expenditures and economic growth. However, none of these studies have examined how various elements effect public expenditures such as fiscal space and tax revenue relates to economic growth of Jordan and how its effect the sartorial growth. Therefore, this is an essential gap that this study strives to fulfill.

2. Note that Jordan is a small economy and yet infrastructure is still underdeveloped; some sectors do not have proper infrastructure and many other sectors have seriously deteriorated infrastructure. The infrastructure is important because government capital expenditures are supposed to be spent on that enable providing public services like infrastructure (education, health, water...).

And since our economy is small, has limited resources and facing political challenges, the budget imposed must be more carefully thought out; the distribution of capital expenditures is more important because Jordan's infrastructure is underdeveloped, and its economy is developing. The point of interest in the impact of capital spending on sectors to lead to greater growth and away from capital spending that does not lead to a result.

\section{Data and Methodology}

\subsection{Theory}

Fiscal policies cannot bring about changes to long-run growth of output in a neoclassical growth model. The introduction of endogenous growth models that incorporate the government sector has led to the opposite conclusion that fiscal policies can affect the long-run growth rate of an economy (e.g. [7]). By assuming producer households, and thus leaving labor as a factor of production and since the government seeking to maximize the utility of the representative household turns out to satisfy this condition even in the second-best case where expenditures are financed by the distorting tax on output, Barro and Sala-i-Martin [8] get the production function as the per capita output $(y)$ is produced by per capita private capital $(\mathrm{k})$ and a publicly provided input $(\mathrm{g})$.

$$
y=f(k, g)
$$

Endogenous growth models shows that productive government expenditures [7, 8, 12] affect the long-run growth rate positively, whereas this is the opposite in the case of proportional taxation. .

The endogenous growth economic theory is important in this research because it can help validate economic development as a direct result of government internal processes. Since the theory contradicts the views of neoclassical economics, it warns against focusing on external factors that influence economic growth [12]. The theory will guide the proposed study by illustrating the important variables and how each one of them should be measured. Stated otherwise, the economic theory can facilitate the cultivation of superior economic growth. Using this model, the current study can focus more on variables that define government capital spending on research and development as well as education, considering that these are believed to be the key factors that promote productivity growth in an economy.

The proposed study is likely to find the endogenous growth economic theory useful in examining the ability of government policies to enhance the growth rate in a country. It could also facilitate an analysis of any increases in returns to scale reported from capital investments, as well as an examination of the private sector investment in research and development [13]. Likewise, the theory may facilitate an analysis of how government policies can encourage investment and extensive innovation in a country, thereby influencing economic development.

Hypotheses

In order to achieve the objectives listed previous and based on the above theory, the proposed study will adopt the following hypothesis:

H1: Government capital expenditures have a positive impact on economic growth.

\subsection{Methodology}

After collecting the required data from Central Bank of Jordan, the Department of Statistics and Ministry of Finance database, and testing thestationarity and co-integration, the study employs an Autoregressive Distributed Lag (ARDL) model that allows the growth in real GDP to be a function of its lagged value to account for any persistent component over time. The ARDL also allows the GDP to be effected by current and lagged values of the independent variables. The study uses the following specification:

1 for more details, see:

Barro, 1990. Government spending in a simple model of endogeneousgrowth, And Barr. andSala-i-Martin, (1992) Public finance in models of economic growth. 


$$
\Delta y_{t}=a_{0}+a_{1} t+b_{0} y_{t-1}+b_{1} x_{t-1}+\sum_{i=1}^{p-1} c_{0, i} \Delta y_{t-i}+\sum_{l=1}^{q-1} c_{l} \Delta x_{t-l}+d \Delta x_{t}+\epsilon_{t}
$$

Where:

$\mathrm{y}_{t}$ is the natural logarithm of real gross domestic product (LRGDP) for year $\mathrm{t}$.

$\mathrm{x}_{t}$ are the independent variables as percentage of GDP (capital expenditures (CAPEX), Gross Fixed Capital Formation (GFCAPF), Net Tax on Production (NETTAX), or General government gross debt $\left.(\mathrm{DEPT})^{2}\right)$.

$a_{0}$ and $a_{1}$ are the estimates of the constant and trend, respectively.

$b_{0}, b_{1}, c_{0, i}, c_{1}$, and $d$ are parameter estimates.

$\epsilon_{t}$ is an $\mathrm{i}, \mathrm{I}, \mathrm{d}$ random error.

\section{Empirical Results}

The study aimed at examining the role of government capital expenditures in economic growth in Jordan during the time period (1977-2016). On average, the current expenditures in Jordan exceeded the capital expenditures during the study period as shown in (figure 1). From the descriptive statistics results (table 1), the mean real domestic product was 9.71, while the capital expenses as a percentage of GDP was 9.16 after making 40 observations except the debt had 29 observation.

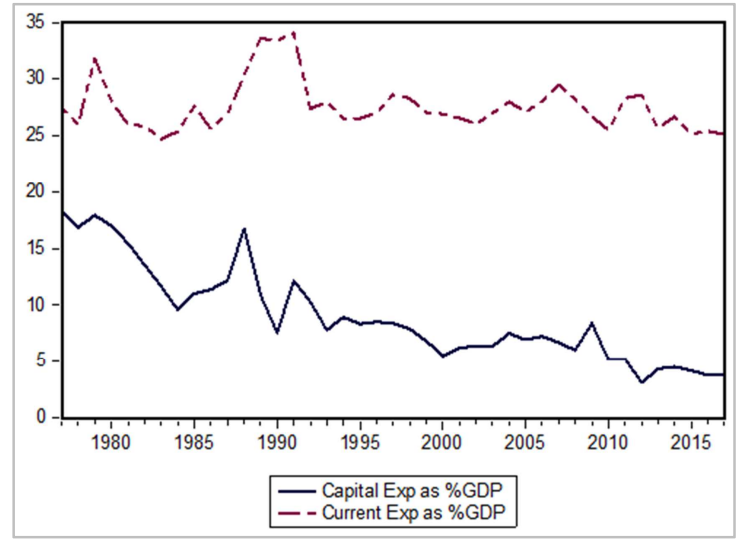

Figure 1. Capital Exp. And Current Exp.

A) Descriptive statistics and correlations: All variables are measured using data from 1977-2016 except for Dept as percentage to GDP variable which startedon 1988.

Table 1. Descriptive Statistics.

\begin{tabular}{llll}
\hline & Mean & Median & Std. Dev \\
\hline LRGDP & 9.715 & 9.681 & 0.218 \\
CAPEX & 9.165 & 8.027 & 4.268 \\
CUREXP & 27.5743 & 27.0134 & 2.24954 \\
GFCAPF & 26.723 & 25.620 & 5.956 \\
NETTAX & 14.041 & 13.725 & 1.231 \\
DEBT & 110.549 & 99.644 & 43.059 \\
\hline
\end{tabular}

Where: CAPEX is capital expenditures as \% GDP, CUREX is Current Exp as \%GDP, GFCAPF is Gross Fixed Capital Formation as \% GDP, NETTAX is Net Tax on Production as \% GDP, or DEPT is General government gross debt as $\% \mathrm{GDP}$.
Table 2. Correlation Probability.

\begin{tabular}{lllll}
\hline & LRGDP & CAPEX & GFCAPF & NETTAX \\
\hline CAPEX & $0.7269-$ & & & \\
& 0.0000 & & & \\
GFCAPF & $0.0625-$ & 0.0336 & & \\
& 0.7474 & 0.8628 & & \\
NETTAX & 0.5811 & $0.4627-$ & 0.2961 & $0.4767-$ \\
& 0.0009 & 0.0115 & 0.1189 & 0.0089 \\
\hline
\end{tabular}

Where: LRGDP is natural logarithm of real GDP, CAPEX is capital expenditures as \% GDP, CUREX is Current Exp as \%GDP, GFCAPF is Gross Fixed Capital Formation as \% GDP, NETTAX is Net Tax on Production as \% GDP, or DEPT is General government gross debt as \% GDP.

From table 2 the correlation analysis, there is a negative and significant correlation between capital expenditures, Net Tax, and Government Debt and economic growth in Jordan, also there is negative correlation between capital expenditures and net tax and positive correlation between capital expenditures and government dept.

B) Stationarity tests:

The Augmented Dickey-Fuller (unit root test) stationarity tests (table 3) shows that all variables; natural logarithm of real GDP, capital expenditures as \% GDP, Gross Fixed Capital Formation as \% GDP, Net Tax on Production as \% GDP, and General government gross debt as \% GDP have first order of integrated.

Table 3. Augmented Dickey Fuller test statistic.

\begin{tabular}{llll}
\hline Variable & ADF stat & Prob & Result \\
\hline LRGDP & -3.78649 & 0.0064 & I (1) \\
CAPEX & -6.67727 & 0 & I (1) \\
GFCAPF & -5.17713 & 0.0001 & I (1) \\
NETTAX & -6.19865 & 0 & I (1) \\
DEBT & -4.07042 & 0.0041 & I (1) \\
\hline
\end{tabular}

Where: LRGDP is natural logarithm of real GDP, CAPEX is capital expenditures as \% GDP, CUREX is Current Exp as \%GDP, GFCAPF is Gross Fixed Capital Formation as \% GDP, NETTAX is Net Tax on Production as \% GDP, or DEPT is General government gross debt as \% GDP.

C) Equilibrating relationship:

Table 4 shown that there is equilibrating relation is exist between the real GDP and each of capital expenditures and government dept, and the equilibrating relation is not exist between the real GDP and each of Gross fixed capital formation and net tax. 
Table 4. ARDL Bounds Test to fine the existent of equilibrating relationship between LRGDP and each independent variables.

\begin{tabular}{lllll}
\hline Independent variable & F-statistic & Min critical value & Maxcritical value & Equilibr-ating relationship \\
\hline CAPEX & 9.47 & 7.46 & 8.27 & Exists \\
GFCAPF & 3.19 & 7.46 & 8.27 & Notexists \\
NETTAX & 4.666 & 7.46 & 8.27 & Not exists \\
DEBT & 72.46 & 3.88 & 4.92 & Exists \\
\hline
\end{tabular}

Where: CAPEX is capital expenditures as \% GDP, CUREX is Current Exp as \%GDP, GFCAPF is Gross Fixed Capital Formation as \% GDP, NETTAX is Net Tax on Production as \% GDP, or DEPT is General government gross debt as \% GDP.

D) Long-run and short-run dynamics of Economic Growth:

Table 5 clarify the positive long run multiplier effect of capital expenditures and government debt oneconomic growth (real GDP), on the other hand table 6 represent the speed of adjustment which is the capital expenditure, gross fixed capital formation and net tax has negative effect in the short term on real GDP, and the government dept has positive short term effect on real GDP.

Table 5. ARDL Cointegrating and Long Run Form to investigate the Long-run coefficients between LRGDP and each independent variables.

\begin{tabular}{lll}
\hline Independent variable & Long-run coefficient & Prob \\
\hline CAPEX & 0.02195 & 0.0097 \\
GFCAPF & 0.001986 & 0.4179 \\
NETTAX & -0.01826 & 0.3412 \\
DEBT & 0.053341 & 0 \\
\hline
\end{tabular}

Where: CAPEX is capital expenditures as \% GDP, CUREX is Current Exp as \%GDP, GFCAPF is Gross Fixed Capital Formation as \% GDP, NETTAX is Net Tax on Production as \% GDP, or DEPT is General government gross debt as \% GDP.

Table 6. ARDL Cointegrating and Long Run Form to investigate the speed of adjustment of errors in equilibrium between LogRGDP and each of the independent variables to long-run equilibrium levels.

\begin{tabular}{lll}
\hline Independent variable & Speed of adjustment & Prob \\
\hline CAPEX & -0.3114 & 0.0002 \\
GFCAPF & -0.13173 & 0.0488 \\
NETTAX & -0.18822 & 0.0099 \\
DEBT & 0.003513 & 0 \\
\hline
\end{tabular}

Where: CAPEX is capital expenditures as \% GDP, CUREX is Current Exp as \%GDP, GFCAPF is Gross Fixed Capital Formation as \% GDP, NETTAX is Net Tax on Production as \% GDP, or DEPT is General government gross debt as \% GDP.

E) Stability Test:

ARDL Cusum model stability test graphs of of LOG GDP and eachindependent variable:

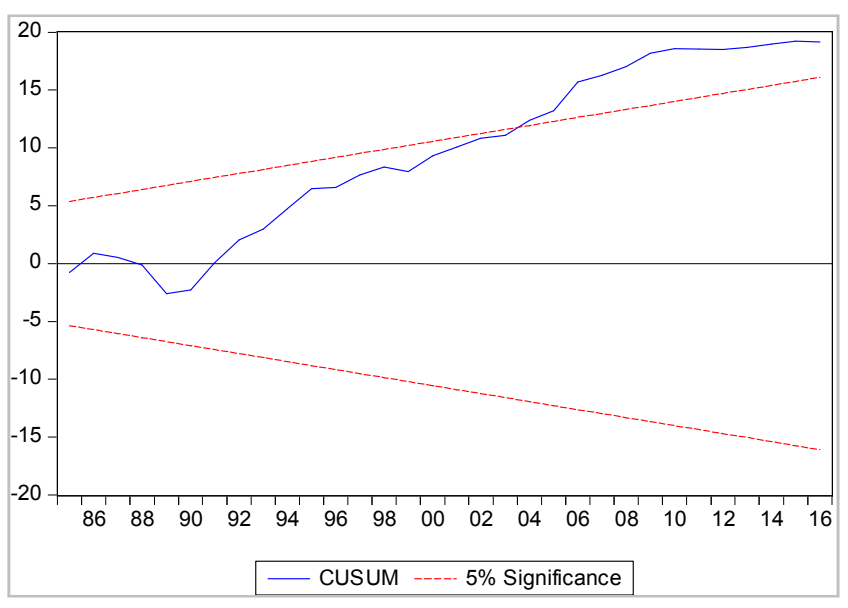

Figure 2. $A R D L(3,4)$ for $\log R G D P$ and capital expenditures as $\% G D P$.

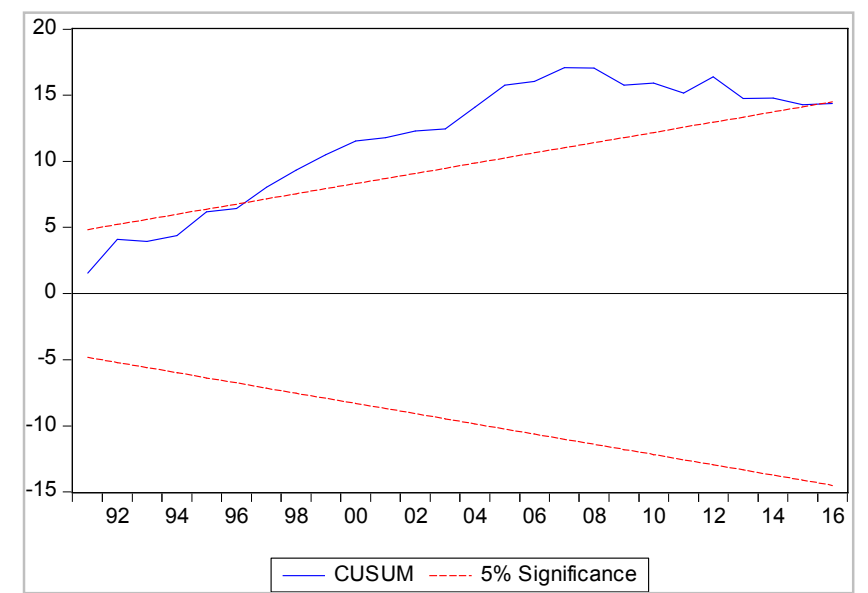

Figure 3. $\operatorname{ARDL}(2,1)$ for $\log R G D P$ and Gross Fixed Capital Formation as $\% G D P$. 


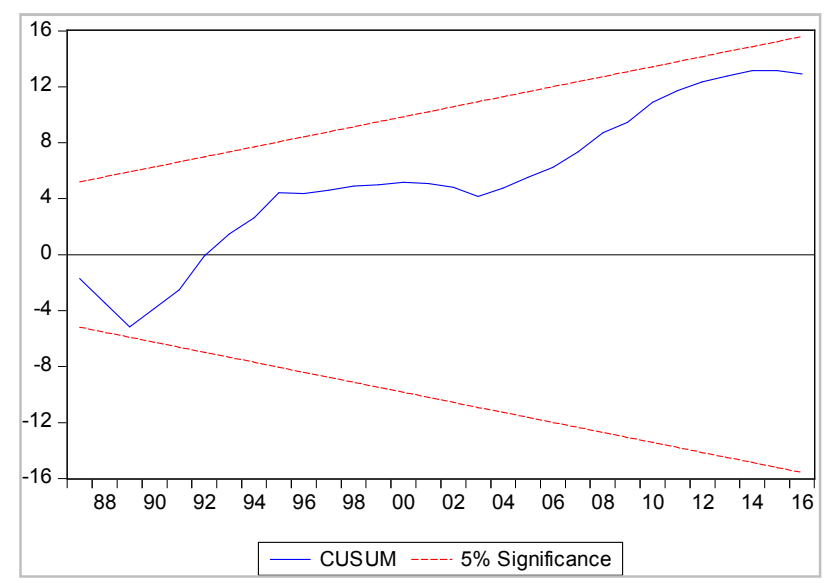

Figure 4. ARDL $(3,1)$ for LogRGDP and Net Tax on Production as $\%$ GDP.

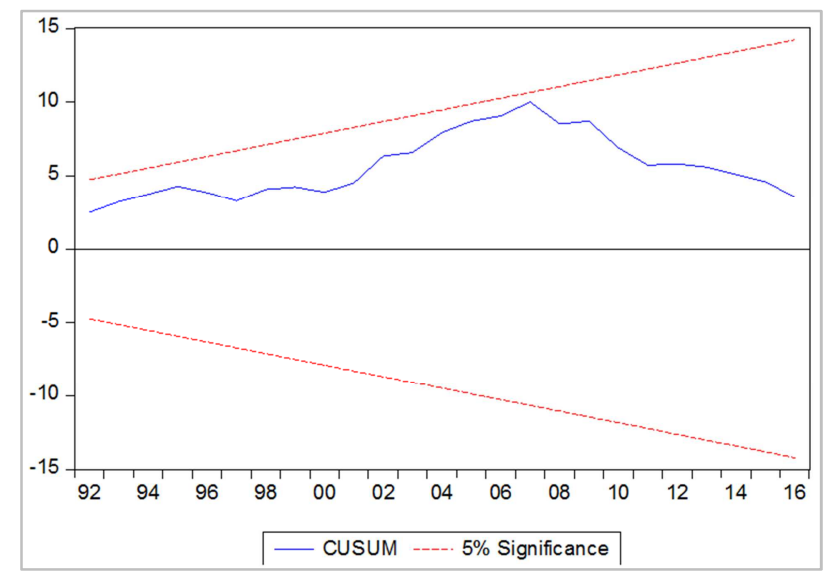

Figure 5. ARDL $(1,1)$ for LogRGDP and General government gross debt as $\% G D P$.

\section{Conclusion}

The main aim of the study is to examine the role of government capital expenditures in economic growth in Jordan during the period between 1977 and 2016. The study tested the relevant data of government capital expenditures at the aggregate level and found a negative and significant correlation between capital expenditures as a percentage of GDP, Net Tax as a percentage of GDP, and Debt as a percentage of GDP and economic growth in Jordan.

Using the Autoregressive Distributed lag model (ARDL), the study found that first, the change in capital expenditures as a percentage of GDP has long-term equilibrium and has a short-term effect, but this result is unreliable due to model instability (CUSUM test forresidual). Second, there is a short-term impact of net fixed capital formation and net tax on economic growth but there is no long-term equilibrium, and finally there is a short-term and long-term effect of government debt on economic growth.

These findings provide significant insights into many aspects of implementing economic policies in Jordan. The findings tend to indicate the need to direct capital toward productive economic activities. This can stimulate activities in diversified economic sectors and help reverse the negative impact of them on economic growth.

\section{Appendix}

1. The study use Government Finance Statistics Manual 2001 and System of National Accounts 2008 to define our variable as the following:

2. GDP is the sum of gross value added by all resident producers in the economy plus any product taxes and minus any subsidies not included in the value of the products. It is calculated without making deductions for depreciation of fabricated assets or for depletion and degradation of natural resources. Data are in constant local currency.

3. Capital Expenditures (or government investment) government spending on goods and services intended to create future benefits, such as infrastructure investment in transport (roads, rail airports), health (water collection and distribution, sewage systems, communication (telephone, radio and tv) and research spending (defense, space, genetics)

4. Gross fixed capital formation (formerly gross domestic fixed investment) includes land improvements (fences, ditches, drains, and so on); plant, machinery, and equipment purchases; and the construction of roads, railways, and the like, including schools, offices, hospitals, private residential dwellings, and commercial and industrial buildings. According to the 1993 SNA, net acquisitions of valuables are also considered capital formation.

5. Net taxes on products (net indirect taxes) are the sum of product taxes less subsidies. Product taxes are those taxes payable by producers that relate to the production, sale, purchase or use of the goods and services. Subsidies are grants on the current account made by general government to private enterprises and unincorporated public enterprises. The grants may take the form of payments to ensure a guaranteed price or to enable maintenance of prices of goods and services below costs of production, and other forms of assistance to producers. Data are in constant local currency.

6. Debt is the entire stock of direct government fixed-term contractual obligations to others outstanding on a particular date. It includes domestic and foreign liabilities such as currency and money deposits, securities other than shares, and loans. It is the gross amount of government liabilities reduced by the amount of equity and financial derivatives held by the government. Because debt is a stock rather than a flow, it is measured as of a given date, usually the last day of the fiscal year.

\section{References}

[1] Abu-Eideh, O. M., 2015. Causality between public expenditures and GDP growth in Palestine: An econometric analysis of Wagner's law. Journal of Economics and Sustainable Development, 6 (2), pp. 189-199. 
[2] Afonso, A. and R. M. Sousa, 2012. The macroeconomic effects of fiscal policy. Applied Economics 44 (34): 44394454.

[3] Al Bataineh, I. M. (2012). The impact of government expenditures on economic growth in Jordan. Interdisciplinary Journal of contemporary research in business 4, no. 6 (2012): 1320-1338.

[4] Al-Fawwaz, T. M., 2015. The impact of government expenditures on economic growth in Jordan (1980-2013). International Business Research, 9 (1), p. 99.

[5] Al-Mazrouei, A. and Nejmeh, E., 2012. The Impact of Public Expenditures in Gross Domestic Product: An Empirical Study on the United Arab Emirates Through the Period (1990-2009). Damascus University Journal for Economic and Legal Science, 28 (1), pp. 611-650.

[6] Al-Shatti, A. S., 2014. The Impact of Public Expenditures on Economic Growth in Jordan. International Journal of Economics and Finance, 6 (10), p. 157.

[7] Barro, R. J., 1990. Government spending in a simple model of endogeneous growth. Journal of political economy, 98 (5, Part 2), pp. S103-S125.

[8] Barro, R. J. and Sala-i-Martin, X. (1992) Public finance in models of economic growth, Review of Economic Studies, 59, 645-61

[9] Blanchard, O. and Perotti, R., 2002. An empirical characterization of the dynamic effects of changes in government spending and taxes on output. the Quarterly Journal of economics, 117 (4), pp. 1329-1368.

[10] Chinweoke, N., Ray, N. and Paschal, N., 2014. Impact of government expenditures on Nigeria's economic growth (1992-2011). The Macrotheme Review: A Multidisciplinary Journal of Global Macro Trends, 3 (7), pp. 79-87.

[11] Colombier, C. and Pickhardt, M. (2005) A note on public input specifications, International Advances in Economic Research, $11,13-18$.

[12] Colombier, C., 2009. Growth effects of fiscal policies: an application of robust modified M-estimator. Applied Economics, 41 (7), pp. 899-912.

[13] Colombier, C., 2011. Does the composition of public expenditures affect economic growth? Evidence from the Swiss case. Applied Economics Letters, 18 (16), pp. 15831589.

[14] Dandan, M. (2011). Government expenditures and economic growth in Jordan. In International Conference on Economics and Finance Research, Singapore, vol. 4, pp. 467-471.

[15] De Castro, F., 2006. The macroeconomic effects of fiscal policy in Spain. Applied Economics, 38 (8), pp. 913-924.
[16] Dritsakis, N. and Adamopoulos, A., 2004. A causal relationship between government spending and economic development: an empirical examination of the Greek economy. Applied Economics, 36 (5), pp. 457-464.

[17] Fatás, A. and Mihov, I., 2001. The effects of fiscal policy on consumption and employment: Theory and evidence. In INSEAD mimeo, CEPR Discussion Paper.

[18] Favero, C. and F. Giavazzi (2007). Debt and the effects of fiscal policy, National Bureau of Economic Research.

[19] Garba, T. (2013). Public Expenditures and Economic Growth: An Application of Cointegration and Granger Causality Tests on Nigeria. Journal of Economic and Social Research 15, no. 11 .

[20] Giordano, R., Momigliano, S., Neri, S. and Perotti, R., 2007. The effects of fiscal policy in Italy: Evidence from a VAR model. European Journal of Political Economy, 23 (3), pp. 707-733.

[21] Kaur, Kirandeep, and OnkarNath Mishra. "Causal Relationship between Government Spending and Economic Growth in Rajasthan: A Toda-Yamamoto Approach." Arthshastra: Indian Journal of Economics \& Research 6, no. 1 (2017): 10-22.

[22] Liu, Y., Lopez, R. A. and Zhu, C., 2014. The impact of four alternative policies to decrease soda consumption. Agricultural and Resource Economics Review, 43 (1), pp. 5368 .

[23] Mehrara, M., Abrishami, H., Boroujli, M. and Amin, M., 2013. Government expenditures and economic growth in Iran. International Letters of Social and Humanistic Sciences, 11, pp. 76-83.

[24] Mountford, A. and Uhlig, H., 2009. What are the effects of fiscal policy shocks? Journal of applied econometrics, 24 (6), pp. $960-992$.

[25] Njuru, S. G., Ombuki, C., Wawire, N. and Okeri, S., 2014. Impact of Government Expenditures on Private Investment in Kenya. Journal of Economics Vol. 2, No. 8 August 2014 ISSN 2347-8233.

[26] Romer D., 2012. "ADVANCED MACROECONOMICS", McGraw-Hill, Fourth Edition, 2012

[27] Udoka, C. O. and Anyingang, R. A., 2015. The Effect of Public Expenditures on the Growth and Development of Nigerian Economy (1980-2012). International Review of Management and Business Research, 4 (3), p. 823.

[28] Yilgör, M., Ertugrul, C. and Celepcioglu, M., 2012. The effect of public expenditures on economic growth: Turkey example. Investment Management and Financial Innovations, 9 (2), pp. 193-202. 